Tropical Journal of Pharmaceutical Research June 2012; 11 (3): 437-444

(C) Pharmacotherapy Group Faculty of Pharmacy, University of Benin

Benin City, 300001 Nigeria.

All rights reserved.

Available online at http://www.tjpr.org http://dx.doi.org/10.4314/tjpr.v11i3.13

\title{
Effect of Boiling on the Cytotoxic and Antioxidant Properties of Aqueous Fruit Extract of Desert Date, Balanites aegyptiaca (L) Delile
}

\author{
Issoufou Amadou ${ }^{1^{*}}$, Guo-Wei Le ${ }^{1}$ and Yong-Hui Shi ${ }^{1}$ \\ ${ }^{1}$ State Key Laboratory of Food Science and Technology, School of Food Science and Technology, Jiangnan \\ University, Wuxi 214122, PR China
}

\begin{abstract}
Purpose: To evaluate the effect of boiling on in vitro bioactivities potency of Balanites aegyptiaca $L$. Delile (desert date) aqueous extract, a juice used traditionally for cooking ready-to-eat millet flour paste. Methods: Desert date fruits $(1.5 \mathrm{~kg})$ were soaked in water (1:2, fruit: water) for $24 \mathrm{~h}$ and sieved. The extract was divided into two parts - fresh extract (Fext) and boiled extract (Bext) which was obtained by boiling a portion of Fext for $10 \mathrm{~min}$. The extracts were tested against the stomach cancer cell line SGC7901 and for antioxidant activity by 1,1-diphenyl-2-icrylhydrazyl DPPH, hydroxyl radical and ferric reducing power methods.

Results: Both fresh extract (Fext) and boiled extract (Bext) exhibited pronounced antioxidant activity with DPPH values of 88.2 and $97.0 \%$, respectively, at hydroxyl radical concentration of $5 \mathrm{mg} / \mathrm{ml}$. The extract contained a significant amount of vitamin C (42.3 and $38.9 \mathrm{mg} / 100 \mathrm{~g}$ for Fext and Bext, respectively). Boiling had significant effect $(p<0.01)$ on its antioxidant activity and also on its cytotoxic effect (56\% and $44 \%$ dead cells respectively for Bext and Fext at respectively, at a concentration of $200 \mu \mathrm{g} / \mathrm{ml})$.
\end{abstract}

Conclusion: It is concluded that $B$. aegyptiaca aqueous extracts have remarkable cytotoxic activity against stomach cancer cell SGC7901.

Keywords: Balanites aegyptiaca, Desert date, Cytotoxicity, Antioxidant activity, Stomach cancer cell line, DPPH radical 


\section{INTRODUCTION}

Balanites aegyptiaca (L.) Delile (Balanitaceae), popularly known as Desert date, is a spiny, evergreen tree commonly grown in the arid regions of Africa, the Middle East, and southern Asia [1]. It is a multi-branched, spiny shrub or tree which grows up to $10 \mathrm{~m}$ in height [1,2]. Almost all the parts of $B$. aegyptiaca plant are traditionally used in several folk medicines. In the Sahara region of Africa, the fruits are used as oral hypoglycemic drug [3] while the stem, root and leaf extracts of $B$. aegyptiaca have commonly been used as various traditional folk medicines especially in Africa and southern Asia. The fruits are also commonly used as purgative, antiparasitic and schistosomicide. The fruit mesocarp contains a large variety of phytochemicals such as pregnane glycosides, coumarins, flavonoids, alkaloids, 6-methyl-diosgenin and furostanol saponins $[3,4]$.

There is a wide range of oxygen-free radicals and other reactive oxygen species (ROS). They include free radicals such as superoxide anion radicals $\left(\mathrm{O}_{2}^{-\bullet}\right)$, hydroxyl radicals $(\mathrm{HO} \cdot)$, and non-free-radical species such as hydrogen peroxide $\left(\mathrm{H}_{2} \mathrm{O}_{2}\right)$ and singlet oxygen $\left({ }^{\prime} \mathrm{O}_{2}\right)$, which may form in the human body and in foods. These radicals induce not only lipid peroxidation that causes deterioration of foods, but also cause oxidative damage by oxidizing biomolecules leading to cell death and tissue damage, such as atherosclerosis, cancer, emphysema, cirrhosis and arthritis $[5,6]$. Currently, the natural antioxidant $\alpha$ tocopherol and some synthetic antioxidants such as butylated hydroxytoluene, butylated hydroxyanisole and propyl gallate are commonly used to mop up free radicals in food and biological systems. However, the use of synthetic antioxidants in food products is regulated owing to their potential health hazards [5].

Cancer is a disorder that develops due to some molecular changes within the cell. It is the third leading cause of death worldwide, after cardiovascular, and infectious and parasitic diseases $[6,7]$. Stomach cancer is one of the most common causes of malignancy-related death worldwide $[1,8]$. Gnoula et al reported diosgenyl saponins isolated from Balanites aegyptiaca Del., consisting of a mixture of balanitin-6 (28\%) and balanitin-7 (72 \%) and which has appreciable anticancer affects on human cancer cell [8]. In China, the annual average mortality rate of gastric carcinoma is as high as 16 per 100 thousand [9]. Chemoprevention and chemotherapy, including the use of natural products, synthetic compounds or dietary supplements, are promising ways to stop or reverse the process of carcinogenesis [8]. Natural products, either as pure compounds or as standardized plant extracts, provide unlimited opportunities for lead drugs because of the unmatched availability of chemical diversity $[7,10]$.

The present study aimed to test the effect of boiling $B$. aegyptiaca aqueous extract on the stomach cancer cell line SGC7901 and on its antioxidant properties. This traditional food is used for cooking millet flour ready-to-eat meal in the Sahel region of Africa [1,2]. Furthermore, the chemical composition of $B$ aegyptiaca aqueous extracts, such as polyphenol, flavonoids, soluble protein and vitamin $\mathrm{C}$, were also determined.

\section{EXPERIMENTAL}

\section{Materials}

The fruits of Balanites aegyptiaca L. Delile were collected from Gao, Mali in September 2010 and supplied by Mss. Foutouma Tounkara, Department of Food Sciences, University of Bamako, Mali. The fruits were identified by $\mathrm{Dr}$ Chiacka Diakite, Section Médecine Traditionnelle, Institut National de Recherche en Santé Publique, Mali, and Dr Tan $\mathrm{Ya} \mathrm{Li}$ of School of Medicine and Pharmaceutics, Jiangnan University,Wuxi, China. A voucher specimen (no. INRSP 
7402) has been kept in the herbarium at the Institut National de Recherche en Santé Publique, Bamako, Mali. Stomach cancer cell line SGC7901 was provided by the Cell Bank of Shanghai Institute of Cell Biology, Chinese Academy of Sciences (Shanghai, China) while 1,1-diphenyl-2-picrylhydrazyl (DPPH) was purchased from Sigma-Aldrich, Inc (Shanghai, China). Vitamin $C$ was purchased from Zhejiang Weishi Biotechnology Co., Ltd (Zhejiang, China). All other reagents used were of analytical grade.

\section{Extract preparation}

The fruits $(1.5 \mathrm{~kg})$ were pealed, soaked in $3 \mathrm{~L}$ of distilled water (1:2) for $24 \mathrm{~h}$ in conical flask, sieved and then filtered through Whatman filter paper no 1 . The extract was divided into two parts - fresh extract (Fext) and boiled extract (Bext) which boiled for $10 \mathrm{~min}$ and cooled. The extracts were concentrated to dryness with a rotary evaporator at reduced pressure, lyophilised, lyophilised (Floormodel freeze dryer, serial No. 050639219 A, Labconco Co., Kansas, USA) and stored at $20^{\circ} \mathrm{C}$ until used

\section{Determination of total phenolic content}

Folin-Ciocalteu method was used for total phenolic content determination as described by Vázquez et al [11]. Folin-Ciocalteu reagent $(2.5 \mathrm{ml})$ was diluted with water $(1: 10$, $\mathrm{v} / \mathrm{v})$, and mixed with $2 \mathrm{ml}$ of $75 \mathrm{~g} / \mathrm{l}$ aqueous solution of sodium carbonate. The resultant solution was added to $0.5 \mathrm{ml}$ of the aqueous desert date extract. The mixture was kept for $5 \mathrm{~min}$ at $50{ }^{\circ} \mathrm{C}$ before measuring the absorbance at $760 \mathrm{~nm}$. The total phenolic content was determined from the calibration curve $\left(y=0.1536 x-0.1433 ; R^{2}=0.9845\right)$ of gallic acid standard solutions (1-20 mg/l) and expressed as $\mathrm{mg}$ gallic acid equivalent $(\mathrm{GAE}) / 100 \mathrm{~g}$ of $B$. aegyptiaca extract.

\section{Flavonoid content determination}

The flavonoid content of the extracts was determined according to the method of Meda et al.[12] with slight modification. The desert date extract $(0.5 \mathrm{ml})$ was mixed with $0.5 \mathrm{ml}$ methanol, $50 \mu \mathrm{l}$ of $10 \% \mathrm{AlCl}_{3}, 50 \mu \mathrm{l}$ of $1 \mathrm{M}$ potassium acetate and $1.4 \mathrm{ml}$ distilled water, and allowed to incubate at room temperature for $30 \mathrm{~min}$. The absorbance of the reaction mixture was then measured at $415 \mathrm{~nm}$ and total flavonoid was calculated using quercetin as standard $\left(\mathrm{y}=0.289 \mathrm{x}-0.0036 ; \mathrm{R}^{2}=\right.$ 0.998 ) as $\mathrm{mg}$ of quercetin equivalent QE.100/mg of extract.

\section{Ascorbic acid and soluble protein determination}

Ascorbic acid was determined according to the 2,6-dichlorophenol-indophenol titration method [13]. The results (titre readings) were expressed as $\mathrm{mg} / 100 \mathrm{~g}$ of the extract. Soluble protein was determined according to the method of Bradford [14] which employed bovine serum albumin as standard for quantitation of microgram quantities of protein utilizing the principle of protein-dye binding.

\section{Anticancer activity assay}

Tryphan blue dye assay method [15] was used to evaluate the in vitro anticancer activity of the extracts. Both extracts (Fext and Bext) were aseptically passed through $0.02 \mu \mathrm{m}$ microbe-free filter (Sigma-Aldrich, Shanghai, China) prior to use. Two samples per concentration $(200,150,100,50$ and 25 $\mu \mathrm{g} / \mathrm{ml}$ ) of Fext and Bext extracts were prepared and $100 \mu \mathrm{l}$ of each was transferred to the required number of graduated tubes. Phosphate buffered saline was added up to make up the volume to $800 \mu \mathrm{l}$. Finally $100 \mu \mathrm{l}$ $\left(2 \times 10^{5}\right.$ cells $\left./ \mathrm{ml}\right)$ of stomach cancer Cell (SGC7901) was added to each of the test tubes which were then were incubated at 37 ${ }^{\circ} \mathrm{C}$ under $5 \% \mathrm{CO}_{2}$ atmosphere for $3 \mathrm{~h}$. A 100 $\mu \mathrm{l}$ aliquot of tryphan blue dye was added to each of the test tubes and the number of dead cells was counted using a haemocytometer under a compound microscope. Cytotoxicity was calculated in percentage using Eq 1. 
Cytotoxicity $(\%)=100 \mathrm{DC} /(\mathrm{DC}+\mathrm{LC})$

where DC is the number of dead cells and LC is the number of living cells.

\section{Evaluation of hydroxyl radical-scavenging activity}

Hydroxyl radical-scavenging assay was carried out using the method described by de Avellar et al [16] with some modifications. Both 1,10-phenanthroline $(0.75 \mathrm{mM})$ and $\mathrm{FeSO}_{4} \quad(0.75 \mathrm{mM})$ were dissolved in phosphate buffer (pH 7.4) and mixed thoroughly. $\mathrm{H}_{2} \mathrm{O}_{2}(0.01 \%)$ and $B$. aegyptiaca extract were added and mixed well. The mixture was incubated at $37{ }^{\circ} \mathrm{C}$ for $60 \mathrm{~min}$ and the absorbance measured using a spectrophotometer at $536 \mathrm{~nm}$ and hydroxyl radical scavenging activity ((HRSA) determined using Eq 2.

$\operatorname{HRSA}(\%)=\left[\left(A_{s}-A_{1}\right) /\left(A_{0}-A_{1}\right)\right] \times 100-$

where $A_{S}$ is the absorbance of the extract $A_{1}$ the absorbance of control solution containing 1,10-phenanthroline, $\mathrm{FeSO}_{4}$ and $\mathrm{H}_{2} \mathrm{O}_{2}$, and $\mathrm{A}_{0}$ the absorbance of blank solution containing 1,10-phenanthroline and $\mathrm{FeSO}_{4}$.

\section{DPPH radical scavenging activity assay}

The scavenging effect of $B$. aegyptiaca extracts on DPPH free radical was measured according to the method of Shimada et al [7] with little modification. Two milliliters of extract $(1.5,3.2$ or $5 \mathrm{mg} / \mathrm{ml})$ were added to 2 $\mathrm{ml}$ of $0.1 \mathrm{mM}$ DPPH dissolved in $95 \%$ ethanol. The mixture was shaken, left for 30 min at room temperature and the absorbance read at $517 \mathrm{~nm}$. A lower absorbance represents a higher DPPH scavenging activity. Scavenging activity was calculated as in Eq 3.

DPPH scavenging activity $(\%)=100\left(A_{b}-\right.$

$\left.A_{e}\right) / A_{b}$

where $A_{b}$ is the absorbance of blank solution and $A_{e}$ the absorbance of the extract solution.

\section{Reducing power assay}

The reducing power of the extracts was measured according to $\mathrm{Wu}$ et al [17]. The extract $(0,0.5,1,1.4,1.8$ or $2 \mathrm{mg} / \mathrm{ml})$ was added to $2 \mathrm{ml}$ of $0.2 \mathrm{M}$ phosphate buffer $(\mathrm{pH}$ 6.6) and $2 \mathrm{ml}$ of $1 \%(\mathrm{w} / \mathrm{v})$ potassium ferricyanide. The mixture was incubated at 50 ${ }^{\circ} \mathrm{C}$ for $20 \mathrm{~min}, 2 \mathrm{ml}$ of $10 \% \mathrm{w} / \mathrm{v}$ trichloroacetic acid (TCA) added and the mixture centrifuged for $10 \mathrm{~min}$ at $3000 \mathrm{~g}$. The supernatant $(2 \mathrm{ml})$ was mixed with $2 \mathrm{ml}$ of distilled water and 0.4 $\mathrm{ml}$ of $0.1 \% \quad(\mathrm{w} / \mathrm{v}) \quad \mathrm{FeCl}_{3}$. After allowing reaction to take place for $10 \mathrm{~min}$, the absorbance of the solution was determined using a spectrophotometer at $700 \mathrm{~nm}$. High absorbance values of the reaction mixture indicate high reducing power.

\section{Statistical analysis}

Statistical analysis was carried out by paired t-test and significant difference was set at $p<$ 0.01 between boiled and fresh extracts. SPSS software, version 18.0 (SPSS, Chicago, IL, USA) was used for the analysis.

\section{RESULTS}

\section{Phytochemical composition of extracts}

The phytochemical composition of the extracts is shown in Table 1 The protein content of the fresh extract (Fext, $4.1 \%$ ) was higher than that of grapes $(3.4 \%)$. The polyphenol and flavonoid contents of $B$. aegytiaca fresh extract (3.51 and $3.21 \%$, respectively) were lower than those of the boiled extracts $(4.67$ and $3.80 \%$, respectively). Vitamin $C$ content was 42.3 and $38.9 \mathrm{mg} / 100 \mathrm{~g}$ for Fext and Bext, respectively, and these values are higher than those for orange fruits.

\section{Hydroxyl radical-scavenging activity}

The results presented in Table 3 show significant difference $(p<0.01)$ between the Bext and Fext at all extract concentrations. However, Fext exhibited superior hydroxyl 
Table 1: Proximate phytochemical composition of aqueous extracts of $B$. aegyptiaca fruit

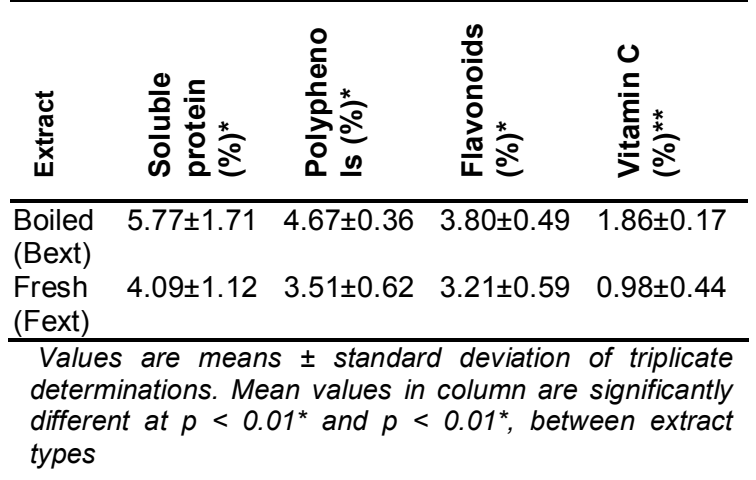

radical scavenging activity to Bext $(79.0$ $97.0 \%$ compared with $61.6-82.5 \%$ for the latter) over the concentration range tested $(1.5-5.0 \mathrm{mg} / \mathrm{ml})$.

\section{Anticancer activity}

The results of in vitro anticancer test are presented in Table 2. The aqueous extracts showed remarkable cytotoxic activity against stomach cancer cell line SGC7901. Both Fext and Bext showed significant effects $(p<0.01)$ on cell proliferation. Cytotoxic activity at extract concentration of $200 \mu \mathrm{g} / \mathrm{ml}$ were pronounced (56 and $44 \%$ for Bext and Fext, respectively).

Tables 2: Effect of boiling B. aegyptiaca fruit aqueous extracts on stomach cancer Cell SGC7901 $\left(2 \times 10^{5}\right.$ cells $/ \mathrm{ml}$ )

\begin{tabular}{|c|c|c|c|c|}
\hline \multirow[t]{2}{*}{ Extract $\left(\mu g \cdot m \Gamma^{1}\right)$} & \multirow[t]{2}{*}{ Sample no. } & \multicolumn{2}{|c|}{ Number of cells } & \multirow[t]{2}{*}{ Dead cells (\%) } \\
\hline & & Live & Dead & \\
\hline \multicolumn{5}{|l|}{ Bext } \\
\hline \multirow[t]{2}{*}{200} & $a$ & 45 & 55 & 56 \\
\hline & b & 43 & 57 & \\
\hline \multirow[t]{2}{*}{150} & a & 55 & 45 & 44 \\
\hline & b & 58 & 42 & \\
\hline \multirow{2}{*}{100} & $\mathrm{a}$ & 66 & 34 & 35 \\
\hline & $b$ & 64 & 36 & \\
\hline \multirow[t]{2}{*}{50} & a & 74 & 26 & 25 \\
\hline & $b$ & 77 & 23 & \\
\hline \multirow[t]{2}{*}{25} & $a$ & 78 & 22 & 21 \\
\hline & $\mathrm{b}$ & 80 & 20 & \\
\hline \multirow{2}{*}{ Contro/** } & $a$ & 91 & 9 & 9 \\
\hline & b & 92 & 8 & \\
\hline \multicolumn{5}{|l|}{ Fext } \\
\hline \multirow[t]{2}{*}{200} & $a$ & 54 & 46 & 44 \\
\hline & $b$ & 68 & 42 & \\
\hline \multirow[t]{2}{*}{150} & $\mathrm{a}$ & 62 & 38 & 39 \\
\hline & $b$ & 60 & 40 & \\
\hline \multirow[t]{2}{*}{100} & $\mathrm{a}$ & 72 & 28 & 30 \\
\hline & $b$ & 69 & 31 & \\
\hline \multirow{2}{*}{50} & $a$ & 75 & 25 & 26 \\
\hline & $b$ & 73 & 27 & \\
\hline \multirow[t]{2}{*}{25} & $a$ & 81 & 19 & 18 \\
\hline & $b$ & 83 & 17 & \\
\hline \multirow[t]{2}{*}{ Control** $^{* *}$} & $a$ & 90 & 10 & 10 \\
\hline & b & 91 & 9 & \\
\hline
\end{tabular}

Bext $=$ boiled extract; Fext $=$ fresh extract; ${ }^{*}$ Mean values in column are significantly different at $(p<0.01)$ between extracts; ${ }^{* *}$ Cell suspension without extract was used as control. 
Tables 3: Scavenging activity of $B$. aegyptiaca fruit aqueous extracts on 1,1-diphenyl-2-picrylhydrazyl (DPPH) and hydroxyl radicals

\begin{tabular}{lcccc}
\hline Extract $(\mathbf{m g} / \mathbf{m L})$ & \multicolumn{2}{c}{ DPPH scavenging (\%) } & \multicolumn{2}{c}{ Hydroxyl radical scavenging (\%) } \\
\cline { 2 - 5 } & Bext & Fext & Bext & Fext \\
\hline 1.5 & $31.3 \pm 2.3$ & $49.1 \pm 1.1$ & $61.6 \pm 2.8$ & $79.0 \pm 1.9$ \\
2.0 & $35.7 \pm 4.1$ & $64.1 \pm 2.9$ & $65.4 \pm 2.3$ & $86.4 \pm 0.5$ \\
3.0 & $60.3 \pm 2.6$ & $80.0 \pm 3.1$ & $77.2 \pm 3.0$ & $89.4 \pm 1.2$ \\
5.0 & $68.2 \pm 2.1$ & $88.2 \pm 2.7$ & $82.5 \pm 2.4$ & $97.0 \pm 1.2$ \\
\hline
\end{tabular}

\section{DPPH radical-scavenging activity}

Table 3 shows that Fext exhibited significantly higher $(p<0.01)$ DPPH radical scavenging activity $(49.1-88.2 \%)$ than Bext $(31.3$ - $68.2 \%$. Fext and Bext radical scavenging activities increased $(p<0.01)$ with increase in extract concentrations. Similar observations were reported by Amadou et al [6] and Vázquez et al [11] for aqueous extracts of fermented soybeans, and chestnut (Castanea sativa) shell and eucalyptus (Eucalyptus globulus) bark extracts, respectively.

\section{Reducing power}

Reducing power data indicate that the aqueous extracts are capable of donating electrons that can react with free radicals to convert them into stable products that strongly inhibit radical chain reaction $[8,19]$. Boiling the extract had a significant effect on its reducing power, as shown in Figure 1. Fext and Bext extracts displayed higher reducing power than vitamin $\mathrm{C}$ at low concentrations.

\section{DISCUSSION}

The antioxidants contained in foods, especially vegetables, are phenolic compounds, flavonoids, ascorbic acid, carotenoids and tocopherol. They are important protective agents for humans; they are also the most plentiful classes of constituents in the plant kingdom, and have been reported to have multiple biological effects [3,11]. Vitamin C consumption has been associated with antioxidant and neuroprotective effects [20]. Although boiling significantly reduced vitamin $C$ content, the pulp of $B$. aegytiaca fruit is still a significant source of a variety of beneficial phytochemicals, including vitamin $\mathrm{C}$.

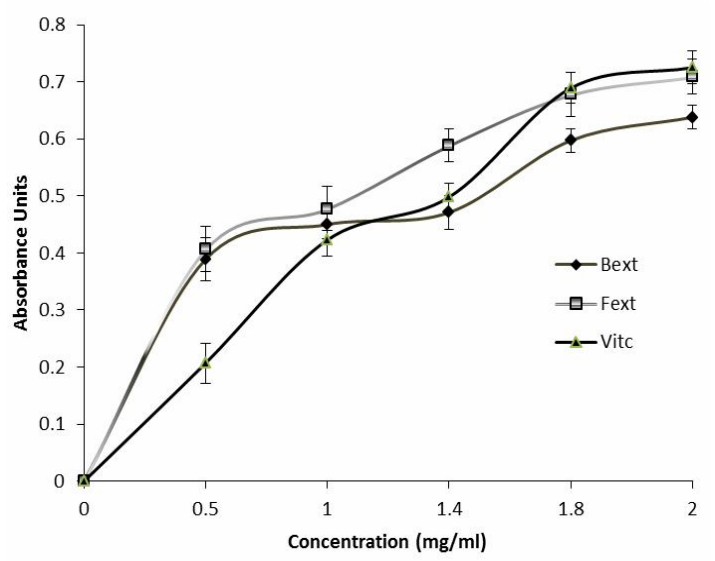

Figure 1: Reducing power of $B$. aegyptiaca fruit aqueous extracts; error bars $=$ standard deviation $(n=3)$

Interestingly, the boiled extract exhibited higher lethal activity on the stomach cancer cell SGC790 at all concentrations than the fresh extract. Gastric cancer is one of the most common causes of malignancy-related death worldwide, and dietary substances are promising ways to stop or reverse the process of carcinogenesis [10]. Despite the solvent used for the extraction, and the extract being boiled, $B$. aegytiaca fruit could be useful in reducing stomach cancer cell proliferation. The effect of boiling on the extract activity against stomach cancer cell SGC790 cell proliferation correlate with increase in polyphenol and flavonoid contents and decrease in vitamin $\mathrm{C}$ level. Various studies have shown that purified compounds 
derived from $B$. aegytiaca fruit extract have significant biological activities $[4,7,9]$.

Free radicals such as hydroxyl radical are generated from sequential reduction of oxygen during the normal course of aerobic metabolism. Over-abundant radicals cause oxidative stress which can lead to cell injury and tissue damage [5]. Balanites aegyptiaca extract can be a potential source of natural antioxidant, and incorporation of these extracts into foods could enhance their nutritional and antioxidant potentials. Our data corroborate those reported by Amadou et al [6] and Shimada et al [7].

DPPH radicals are widely used to investigate the scavenging activity of natural compounds. These free radicals are stable in ethanol and show maximum absorbance at $517 \mathrm{~nm}$. When DPPH radicals encounter a protondonating substance such as an antioxidant, the radicals are scavenged and their absorbance reduced [6]. B. aegyptiaca extracts showed significant scavenging activities against DPPH radicals. This is not surprising since the fruit mesocarp contains a large variety of phytochemicals amongst which are the pregnane glycosides, coumarins, flavonoids, 6-methyl-diosgenin and furostanol saponins [3,4], which could be electron donors, and hence can react with free radicals to convert them to more stable products and terminate the radical chain reaction.

Previous studies indicate that antioxidant activity and reducing power are directly related $[6,19]$. The reducing power of fermented foxtail millet extracts increased with increasing concentrations and it was observed that boiling the extract lowered reducing power over a concentration range of 0.5 to $2 \mathrm{mg} / \mathrm{ml}$.

\section{CONCLUSION}

The aqueous extract of $B$. aegyptiaca fruit showed remarkable cytotoxic activity against the stomach cancer cell SGC7901. The activities were most likely due to bertain phytochemical constituents of the extracts. Evaluation of both biological properties and boiling conditions that can influence the stability and activity of millet flour mixed with the aqueous extract of $B$. aegyptiaca fruit is underway, with a view to formulating food products with optimum health benefits.

\section{ACKNOWLEDGEMENT}

This research was supported by the National Natural Science Foundation of China (no. 30671525), and the National High Technology Research and Development Program ("863" Program) of China (no. 2007. AA10Z325), 111 project-B07029. Thanks to Bian Yuan Yuan for making cultured stomach cancer cells SGC7901 available for the experiment. The helpful suggestions and comments of Mohamed Beva Kelfala Foh, Amza Tidjani and Maureen J Cheserek, are gratefully acknowledged. The authors also wish to thank $\mathrm{Dr}$ Chiacka Diakite of Section Médecine Traditionnelle, Institut National de Recherche en Santé Publique, (Bamako, Mali), for the collection and botanical identification of the fruits used in this study.

\section{REFERENCES}

1. Yadav JP, Panghal M. Balanites aegyptiaca (L.) Del. (Hingot): A review of its traditional uses, phytochemistry and pharmacological properties. Int J Green Pharm. 2010; 4: 140 146.

2. Chothani DL, Vaghasiya HU. A review on Balanites aegyptiaca Del (desert date): phytochemical constituents, traditional uses, and pharmacological activity. Pharmacog Rev 2011; 5: 55-62.

3. Kamel MS. A furostanol saponin from fruits of Balanites aegyptiaca. Phytochemistry 1998; 48: 755-757.

4. Sarker $S D$, Bartholomew B, Nash RJ. Alkaloids from Balanites aegyptiaca. Fitoterapia 2000; 71: 328-330.

5. Halliwell B. Gutteridge JMC. Free radical in Biology and Medicine, 3rd ed., UK: Oxford University Press, 1999.

6. Amadou I, Guo-Wei L, Yong-Hui S, Sun J. Reducing, radical scavenging, and chelation properties of fermented soy protein meal hydrolysate by Lactobacillus plantarum Lp6. Int J Food Properties 2011: 14(3): 654-665. 
7. Shimada K, Fujikawa K, Yahara K, Nakamura $T$. Antioxidative properties of xanthan on the antioxidation of soybean oil in cyclodextrin emulsion. J Agric Food Chem. 1992; 40: 945948.

8. Gnoula C, Megalizzi V, Neve ND, Sauvage $S$, Ribaucour F, Guissou P, Duez P, Dubois J, Ingrassia $L$, Lefranc $F$, Kiss $R$, Mijatovic $T$. Balanitin-6 and 7: Diosgenyl saponins isolated from Balanites aegyptiaca Del. display significant anti-tumor activity in vitro and in vivo. Int J Oncol. 2008; 32: 5-15.

9. Xue $F B, X u Y Y$, Wan $Y$, Pan BR, Ren J, Fan DM. Association of $H$. pylori Infection with gastric carcinoma: a Meta-analysis. World J Gastroenterol. 2001; 7: 801-804.

10. Cos P, Vlietinck AJ, Berghe DV, Maes L. Antiinfective potential of natural products: How to develop a stronger in vitro 'proof-ofconcept'. J Ethnopharmacol. 2006; 106: 290302.

11. Vázquez $G$, Fontenl $E$, Santo J, Freir MS, González-Álvarez J, Antorrena G. Antioxidant activity and phenolic content of chestnut (Castanea sativa) shell and eucalyptus (Eucalyptus globulus) bark extracts. Ind Crops Products 2008; 28: 279-285.

12. Meda A, Lamien CE, Romito M, Millogo J, Nacoulma OG. Determination of the total phenolic, flavonoid and proline contents in Burkina Fasan honey, as well as their radical scavenging activity. Food Chem. 2005; 91: 571-577.

13. James CS. Analytical chemistry of foods. Chapman and Hall, New York, 1995; pp 137-139.

14. Bradford MM. A rapid and sensitive method for the quantitation of microgram quantities of protein utilizing the principle of protein-dye binding. Anal Biochem. 1976; 72: 248-254.

15. Rajkapoor B. Jayakar B. Murugesh N. Antitumour activity of Bauhinia variegata on Dalton's ascitic Lymphoma. J Ethnopharmacol. 2003: 83:107-109.

16. de Avellar IG, Magalhaes MM, Silva AB, Souza LL, Leitao AC, Hermes-Lima M. Reevaluating the role of 1,10-phenanthroline in oxidative reactions involving ferrous ions and DNA damage. Biochimica et Biophysica Acta 2004; 1675: 46-53.

17. Wu HC, Chen HM, Shiau CY. Free amino acids and peptides as related to antioxidant properties in protein hydrolysates of mackerel (Scomber austriasicus). Food Res Int. 2003; 36: 949957.

18. USDA. National Nutrient Database for Standard Reference, Release 23 (2010). Accessed May 24. http://www.ars.usda.gov/ba/bhnrc/ndl.

19. Owolabi OJ, Amaechina FC, Okoro M. Effect of ethanol leaf extract of Newboulda laevis on blood glucose levels of diabetic rats. Trop $J$ Pharm Res. 2011; 10(3): 249-254.

20. Santos LFL. Freitas RLM. Xavier SML. Saldanha GB. Freitas RM. Neuroprotective actions of vitamin $C$ related to decreased lipid peroxidation and increased catalase activity in adult rats after pilocarpine-induced seizures. Pharmacol Biochem Behv. 2008; 89: 1-5. 